\title{
Loading-dependent elemental composition of $\alpha$-pinene SOA particles
}

\author{
J. E. Shilling ${ }^{1, *}$, Q. Chen ${ }^{1}$, S. M. King ${ }^{1}$, T. Rosenoern ${ }^{1}$, J. H. Kroll ${ }^{2}$, D. R. Worsnop ${ }^{2}$, P. F. DeCarlo ${ }^{3,4, * *}$, A. C. Aiken ${ }^{4,5}$, \\ D. Sueper ${ }^{2,4,5}$, J. L. Jimenez ${ }^{4,5}$, and S. T. Martin ${ }^{1,6}$ \\ ${ }^{1}$ School of Engineering and Applied Sciences, Harvard University, Cambridge, MA 02138, USA \\ ${ }^{2}$ Aerodyne Research, Inc., Billerica, MA 08121, USA \\ ${ }^{3}$ Department of Atmospheric and Oceanic Sciences, University of Colorado, Boulder, CO 80309, USA \\ ${ }^{4}$ Cooperative Institute for Research in the Environmental Sciences (CIRES), Univ. of Colorado, Boulder, CO 80309, USA \\ ${ }^{5}$ Department of Chemistry and Biochemistry, University of Colorado, Boulder, CO 80309, USA \\ ${ }^{6}$ Department of Earth and Planetary Sciences, Harvard University, Cambridge, MA 02138, USA \\ *now at: Pacific Northwest National Laboratory, Atmospheric Sciences and Global Change Division, Richland, \\ WA 99352, USA \\ ** now at: Paul Scherrer Institut, Laboratory of Atmospheric Chemistry, Villigen-PSI, 5232, Switzerland
}

Received: 8 July 2008 - Published in Atmos. Chem. Phys. Discuss.: 13 August 2008

Revised: 11 December 2008 - Accepted: 11 December 2008 - Published: 2 February 2009

\begin{abstract}
The chemical composition of secondary organic aerosol (SOA) particles, formed by the dark ozonolysis of $\alpha$ pinene, was characterized by a high-resolution time-of-flight aerosol mass spectrometer. The experiments were conducted using a continuous-flow chamber, allowing the particle mass loading and chemical composition to be maintained for several days. The organic portion of the particle mass loading was varied from 0.5 to $>140 \mu \mathrm{g} / \mathrm{m}^{3}$ by adjusting the concentration of reacted $\alpha$-pinene from 0.9 to $91.1 \mathrm{ppbv}$. The mass spectra of the organic material changed with loading. For loadings below $5 \mu \mathrm{g} / \mathrm{m}^{3}$ the unit-mass-resolution $\mathrm{m} / z 44$ $\left(\mathrm{CO}_{2}^{+}\right)$signal intensity exceeded that of $\mathrm{m} / \mathrm{z}, 43$ (predominantly $\mathrm{C}_{2} \mathrm{H}_{3} \mathrm{O}^{+}$), suggesting more oxygenated organic material at lower loadings. The composition varied more for lower loadings ( 0.5 to $\left.15 \mu \mathrm{g} / \mathrm{m}^{3}\right)$ compared to higher loadings ( 15 to $>140 \mu \mathrm{g} / \mathrm{m}^{3}$ ). The high-resolution mass spectra showed that from $>140$ to $0.5 \mu \mathrm{g} / \mathrm{m}^{3}$ the mass percentage of fragments containing carbon and oxygen $\left(\mathrm{C}_{\mathrm{x}} \mathrm{H}_{\mathrm{y}} \mathrm{O}_{\mathrm{z}}^{+}\right)$monotonically increased from $48 \%$ to $54 \%$. Correspondingly, the mass percentage of fragments representing $\mathrm{C}_{\mathrm{x}} \mathrm{H}_{\mathrm{y}}^{+}$decreased from $52 \%$ to $46 \%$, and the atomic oxygen-to-carbon ratio
\end{abstract}

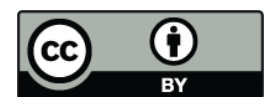

Correspondence to: S. T. Martin (scot_martin@harvard.edu) increased from 0.29 to 0.45 . The atomic ratios were accurately parameterized by a four-product basis set of decadal volatility (viz. $0.1,1.0,10,100 \mu \mathrm{g} / \mathrm{m}^{3}$ ) employing products having empirical formulas of $\mathrm{C}_{1} \mathrm{H}_{1.32} \mathrm{O}_{0.48}, \mathrm{C}_{1} \mathrm{H}_{1.36} \mathrm{O}_{0.39}$, $\mathrm{C}_{1} \mathrm{H}_{1.57} \mathrm{O}_{0.24}$, and $\mathrm{C}_{1} \mathrm{H}_{1.76} \mathrm{O}_{0.14}$. These findings suggest considerable caution is warranted in the extrapolation of laboratory results that were obtained under conditions of relatively high loading (i.e., $>15 \mu \mathrm{g} / \mathrm{m}^{3}$ ) to modeling applications relevant to the atmosphere, for which loadings of 0.1 to $20 \mu \mathrm{g} / \mathrm{m}^{3}$ are typical. For the lowest loadings, the particle mass spectra resembled observations reported in the literature for some atmospheric particles.

\section{Introduction}

Atmospheric particles influence visibility, climate, and human health (Seinfeld and Pankow, 2003). For many clean and polluted environments, the organic fraction of these particles contributes 20 to $70 \%$ of the total non-refractory mass (Zhang et al., 2007). At present, however, organic mass loadings are underestimated in many cases when the predictions of chemical transport models are compared to atmospheric measurements (Heald et al., 2005; Johnson et al., 2006; Volkamer et al., 2006). A significant fraction of the

Published by Copernicus Publications on behalf of the European Geosciences Union. 
organic mass, balanced by primary emissions (POA), is associated with secondary organic aerosol (SOA) production (Zhang et al., 2005a, b; Johnson, 2006; Takegawa et al., 2006; Volkamer et al., 2006; Zhang et al., 2007). An improved quantitative and mechanistic understanding of the formation, the chemistry, and the properties of SOA-bearing particles is therefore an important goal.

For predicting atmospheric loadings, chemical transport models widely employ semivolatile-partitioning theory (Pankow, 1994a, b) based on parameterizations of laboratory-measured SOA particle mass yield (Chung and Seinfeld, 2002). Semivolatile-partitioning theory predicts organic particle mass by consideration of the reversible absorption of semivolatile species. A molecule found both in the gas and particles of an aerosol increasingly partitions into the latter for higher mass loadings of the organic particles. Moreover, species having lower vapor pressures in pure form partition to a greater extent to the particle phase because activity-based corrections are minor in most cases (Bowman and Karamalegos, 2002).

There may be several reasons for the differences between observations and model predictions (Heald et al., 2005; Johnson et al., 2006; Volkamer et al., 2006). Presto and Donahue (2006) emphasized that the parameterizations used in chemical transport models for SOA particle mass yield require significant extrapolations from laboratory conditions. For example, conditions of organic mass loadings greater than $15 \mu \mathrm{g} / \mathrm{m}^{3}$ have been widely used in laboratory studies, whereas typical atmospheric loadings are between 0.1 and $20 \mu \mathrm{g} / \mathrm{m}^{3}$. Shilling et al. (2008) carried out further studies and measured particle mass yields were even higher than those predicted by Presto and Donahue (2006). Some reconciliation between models and observations is therefore possible using these updated laboratory results.

In the framework of partitioning theory, the higher yields measured in the laboratory suggest the formation of molecules of lower vapor pressure than expected from the gas-phase chemistry mechanism (Jenkin, 2004). Alternatively, the higher yields suggest that a simplified mechanism of SOA formation, specifically gas-phase production of semivolatile species followed by partitioning, may be incomplete. Insights into and constraints on these possibilities can be expected from laboratory studies that characterize SOA particle chemical composition at mass loadings similar to those of the atmosphere. The inaccuracy associated with extrapolations of particle yield to low loadings suggests that changes in chemical composition can also be expected because yield is governed by composition through volatility. Measurements under these conditions can provide insights into SOA particle production and subsequent transformation and aging.

In this work, the chemical composition of SOA particles is characterized using an Aerodyne high-resolution time-offlight aerosol mass spectrometer (HR-ToF-AMS). The SOA is formed by the dark ozonolysis of $\alpha$-pinene using the continuous-flow mode of the Harvard Environmental Chamber. Although past studies have reported on the AMS mass spectra of $\alpha$-pinene SOA, they have done so only for high organic loadings $\left(>15 \mu \mathrm{g} / \mathrm{m}^{3}\right)$ and at unit-mass resolution (Bahreini et al., 2005; Alfarra et al., 2006; Zhang et al., 2006; Song et al., 2007). For the measurements described herein, organic particle mass loadings from 0.5 to $>140 \mu \mathrm{g} / \mathrm{m}^{3}$ are employed. Moreover, the high-resolution mode of the AMS can distinguish the relative contributions by the $\mathrm{C}_{\mathrm{x}} \mathrm{H}_{\mathrm{y}} \mathrm{O}_{\mathrm{z}}^{+}$and $\mathrm{C}_{\mathrm{x}} \mathrm{H}_{\mathrm{y}}^{+}$families to the organic particle mass, which allows atomic $\mathrm{O} / \mathrm{C}$ and $\mathrm{H} / \mathrm{C}$ ratios to be determined. The experimental strategy is to systematically vary the mass loading while other reaction conditions, such as the aging time and the oxidant concentration, are left unchanged among experiments. The gas-phase reaction products predicted by the Leeds Master Chemical Mechanism (MCM v3.1) (Saunders et al., 2003) are similar among experiments (Table 1), and any changes in the particle organic composition for increasing loading can therefore be interpreted as primarily due to the increasing partitioning of semivolatile molecules into the particle phase.

\section{Experimental}

Secondary organic aerosol was generated from the dark ozonolysis of 0.9 to $91.1 \mathrm{ppbv}$ of $\alpha$-pinene in the Harvard Environmental Chamber (HEC). The HEC, consisting of a $4.7 \mathrm{~m}^{3}$ PFA Teflon bag housed in a temperature-controlled room, was described previously (King et al., 2007; Shilling et al., 2008). For the experiment described in this paper, reaction conditions were $25^{\circ} \mathrm{C}$ and $40 \% \mathrm{RH}$ using solid $\left(\mathrm{NH}_{4}\right)_{2} \mathrm{SO}_{4}$ as seed particles, excess 1-butanol as an $\mathrm{OH}$ scavenger ( 0.94 to $95 \mathrm{ppmv}$ ), and $300 \mathrm{ppbv}_{3}$ as the oxidant. The molar ratio of 1-butanol to $\alpha$-pinene was held constant at 1040 in all experiments.

The chamber was operated in a continuous-flow mode, for which the input flow of reactants was balanced by exhaust and sampling outflow (Kleindienst et al., 1999; Seinfeld et al., 2003; King et al., 2007; Shilling et al., 2008). After an initial transient period of 12 to $24 \mathrm{~h}$, reactants and products reached their steady-state chemical composition, and an experiment was run for several days at a specific inflow concentration of $\alpha$-pinene while data were recorded. The total flow rate of $21.1 \mathrm{sLpm}$ through the chamber corresponded to a mean residence time of $3.4 \mathrm{~h}$. Humidity and ozone were maintained at constant levels using feedback controls.

During the course of the experiments, the chamber was periodically cleaned, especially before conducting experiments for the lowest SOA mass loadings, by exposure to ozone concentrations of ca. $1 \mathrm{ppmv}$ for at least $24 \mathrm{~h}$ at $40^{\circ} \mathrm{C}$, followed by flushing with clean air for several hours. Following cleaning, particle concentrations in the chamber were below $5 / \mathrm{cm}^{3}$. 
Table 1. Gas-phase products predicted by the MCM model v3.1 (Saunders et al., 2003) for the dark ozonolysis of 0.9, 6.7, and 91.1 ppbv reacted $\alpha$-pinene. Results are shown as the percent contribution of each species on a number-concentration basis to the total of all products. For 6.7 and $91.1 \mathrm{ppbv}$, also shown are the ratios of the percent contribution of each species at those concentrations to that at 0.9 ppbv. Conditions: $25^{\circ} \mathrm{C}, 40 \% \mathrm{RH}$, dry $\left(\mathrm{NH}_{4}\right)_{2} \mathrm{SO}_{4}$ seed particles, $300 \mathrm{ppbv}$ ozone, $3.4 \mathrm{~h}$ residence time, and 0.94 to $95 \mathrm{ppmv} 1$-butanol (1040 $\times \alpha$ pinene). The model does not treat formation of SOA particle mass.

\begin{tabular}{|c|c|c|c|c|c|c|}
\hline \multirow[b]{2}{*}{ MCM name } & \multirow[b]{2}{*}{ Formula } & \multirow{2}{*}{$\frac{0.9 \mathrm{ppbv}}{\text { Percent of Total }}$} & \multicolumn{2}{|l|}{$6.7 \mathrm{ppbv}$} & \multicolumn{2}{|l|}{$91.1 \mathrm{ppbv}$} \\
\hline & & & Percent of Total & ratio & Percent of Total & ratio \\
\hline $\mathrm{C} 107 \mathrm{OOH}$ & $\mathrm{C}_{10} \mathrm{H}_{17} \mathrm{O}_{4}$ & 18.40 & 19.15 & 1.04 & 19.13 & 1.04 \\
\hline PINONIC & $\mathrm{C}_{10} \mathrm{H}_{16} \mathrm{O}_{3}$ & 13.08 & 13.09 & 1.00 & 13.04 & 1.00 \\
\hline $\mathrm{C} 97 \mathrm{OOH}$ & $\mathrm{C}_{9} \mathrm{H}_{17} \mathrm{O}_{4}$ & 8.83 & 10.02 & 1.14 & 10.63 & 1.20 \\
\hline PINAL & $\mathrm{C}_{10} \mathrm{H}_{16} \mathrm{O}_{2}$ & 7.83 & 7.84 & 1.00 & 7.82 & 1.00 \\
\hline $\mathrm{C} 108 \mathrm{OOH}$ & $\mathrm{C}_{10} \mathrm{H}_{16} \mathrm{O}_{5}$ & 6.82 & 8.56 & 1.25 & 9.65 & 1.41 \\
\hline $\mathrm{C} 89 \mathrm{CO} 2 \mathrm{H}$ & $\mathrm{C}_{9} \mathrm{H}_{14} \mathrm{O}_{3}$ & 5.60 & 5.69 & 1.02 & 5.72 & 1.02 \\
\hline $\mathrm{C} 107 \mathrm{O} 2$ & $\mathrm{C}_{10} \mathrm{H}_{16} \mathrm{O}_{2}$ & 3.86 & 1.56 & 0.40 & & \\
\hline $\mathrm{C} 107 \mathrm{OH}$ & $\mathrm{C}_{10} \mathrm{H}_{17} \mathrm{O}_{3}$ & 3.67 & 4.15 & 1.13 & 4.45 & 1.21 \\
\hline $\mathrm{C} 96 \mathrm{OH}$ & $\mathrm{C}_{9} \mathrm{H}_{16} \mathrm{O}_{2}$ & 3.72 & 3.80 & 1.02 & 3.83 & 1.03 \\
\hline NORPINAL & $\mathrm{C}_{9} \mathrm{H}_{14} \mathrm{O}_{2}$ & 3.72 & 3.80 & 1.02 & 3.83 & 1.03 \\
\hline PINIC & $\mathrm{C}_{9} \mathrm{H}_{14} \mathrm{O}_{4}$ & 3.11 & 3.17 & 1.02 & 3.19 & 1.03 \\
\hline $\mathrm{C} 921 \mathrm{OOH}$ & $\mathrm{C}_{9} \mathrm{H}_{17} \mathrm{O}_{5}$ & 2.28 & 2.63 & 1.15 & 2.82 & 1.24 \\
\hline $\mathrm{C} 109 \mathrm{OOH}$ & $\mathrm{C}_{10} \mathrm{H}_{16} \mathrm{O}_{4}$ & 1.80 & 1.68 & 0.94 & 1.57 & 0.87 \\
\hline $\mathrm{C} 96 \mathrm{OOH}$ & $\mathrm{C}_{9} \mathrm{H}_{16} \mathrm{O}_{3}$ & 1.93 & 1.81 & 0.94 & 1.70 & 0.88 \\
\hline $\mathrm{C} 97 \mathrm{O} 2$ & $\mathrm{C}_{9} \mathrm{H}_{16} \mathrm{O}_{4}$ & 1.90 & 0.84 & 0.44 & & \\
\hline $\mathrm{C} 89 \mathrm{OOH}$ & $\mathrm{C}_{8} \mathrm{H}_{14} \mathrm{O}_{3}$ & 2.04 & 2.31 & 1.14 & 2.45 & 1.20 \\
\hline $\mathrm{C} 812 \mathrm{OOH}$ & $\mathrm{C}_{8} \mathrm{H}_{12} \mathrm{O}_{5}$ & 1.99 & 2.16 & 1.08 & 2.20 & 1.11 \\
\hline $\mathrm{C} 108 \mathrm{O} 2$ & $\mathrm{C}_{10} \mathrm{H}_{15} \mathrm{O}_{5}$ & 1.44 & & & & \\
\hline HOPINONIC & $\mathrm{C}_{10} \mathrm{H}_{14} \mathrm{O}_{4}$ & 1.40 & 1.43 & 1.02 & 1.43 & 1.02 \\
\hline C109CO & $\mathrm{C}_{10} \mathrm{H}_{14} \mathrm{O}_{3}$ & 1.31 & 1.33 & 1.01 & 1.33 & 1.02 \\
\hline $\mathrm{C} 109 \mathrm{OH}$ & $\mathrm{C}_{10} \mathrm{H}_{16} \mathrm{O}_{3}$ & 1.30 & 1.32 & 1.02 & 1.32 & 1.02 \\
\hline $\mathrm{C} 811 \mathrm{OH}$ & $\mathrm{C}_{8} \mathrm{H}_{14} \mathrm{O}_{3}$ & 1.28 & 1.33 & 1.04 & 1.36 & 1.06 \\
\hline C721CHO & $\mathrm{C}_{8} \mathrm{H} 12 \mathrm{O}_{3}$ & 1.28 & 1.33 & 1.04 & 1.36 & 1.06 \\
\hline $\mathrm{C} 813 \mathrm{OOH}$ & $\mathrm{C}_{8} \mathrm{H}_{14} \mathrm{O}_{6}$ & 0.77 & 1.02 & 1.31 & 1.17 & 1.52 \\
\hline
\end{tabular}

An Aerodyne HR-ToF AMS was used to measure the organic particle mass loading and to characterize the chemical composition of the particles (Jayne et al., 2000; DeCarlo et al., 2006; Canagaratna et al., 2007). Mass loadings determined using the AMS, which ranged from 0.5 to $>140 \mu \mathrm{g} / \mathrm{m}^{3}$, agreed with density-compensated volume loading measured using a scanning mobility particle sizer (SMPS) (Shilling et al., 2008). In the experimental protocol, the AMS alternated every 10 to 30 min between (i) a highresolution "W-" mode having a resolution of ca. 5200 and (ii) a higher sensitivity, lower resolution "V-" mode having a resolution of ca. 2400. Within the V-mode, the instrument ran in mass spectrum (MS) and particle-time-of-flight (PToF) submodes for equal time periods (Jayne et al., 2000; Jimenez et al., 2003). The PToF mode, which classified mass spectra by vacuum aerodynamic diameter, was employed to distinguish between the gas- and particle-phase contributions of some organic ions (viz., $\mathrm{m} / \mathrm{z}, 28,29,40$, and 44). Mass spectra at loadings below $5 \mu \mathrm{g} / \mathrm{m}^{3}$ were placed into several bins according to the concentration of $\alpha$-pinene precursor and av- eraged within a bin as an approach for decreasing the interference effects of variable gas-phase $\mathrm{CO}_{2}$.

A fragmentation table was used to deconvolute the V-mode mass spectra into organic, sulfate, ammonium, and air components (Allan et al., 2004). Only the organic component is shown in the mass spectra presented in this paper. Wmode spectra were analyzed with additional software for fitting the high-resolution peaks (DeCarlo et al., 2006). Several changes were made to the standard fragmentation table (Allan et al., 2004; Aiken et al., 2008) to ensure accurate analysis of the organic particle mass. Specifically, the fragmentation table at $\mathrm{m} / \mathrm{z} 29,40$, and 44 was adjusted on an experiment-by-experiment basis to account for the variability of gas-phase contributions. On the basis of observations made for the high-loading experiments, the particlephase signal intensity at $\mathrm{m} / z 28$ (from $\mathrm{CO}^{+}$) was calculated as 1.075 times that of the particle-phase $\mathrm{CO}_{2}^{+}$signal $(\mathrm{m} / \mathrm{z}$ $44)$. This value was similar to values of $1-1.25$ reported by Zhang et al. (2005b), DeCarlo et al. (2006), and Takegawa et al. (2007) for ambient particles. The signal intensities of 

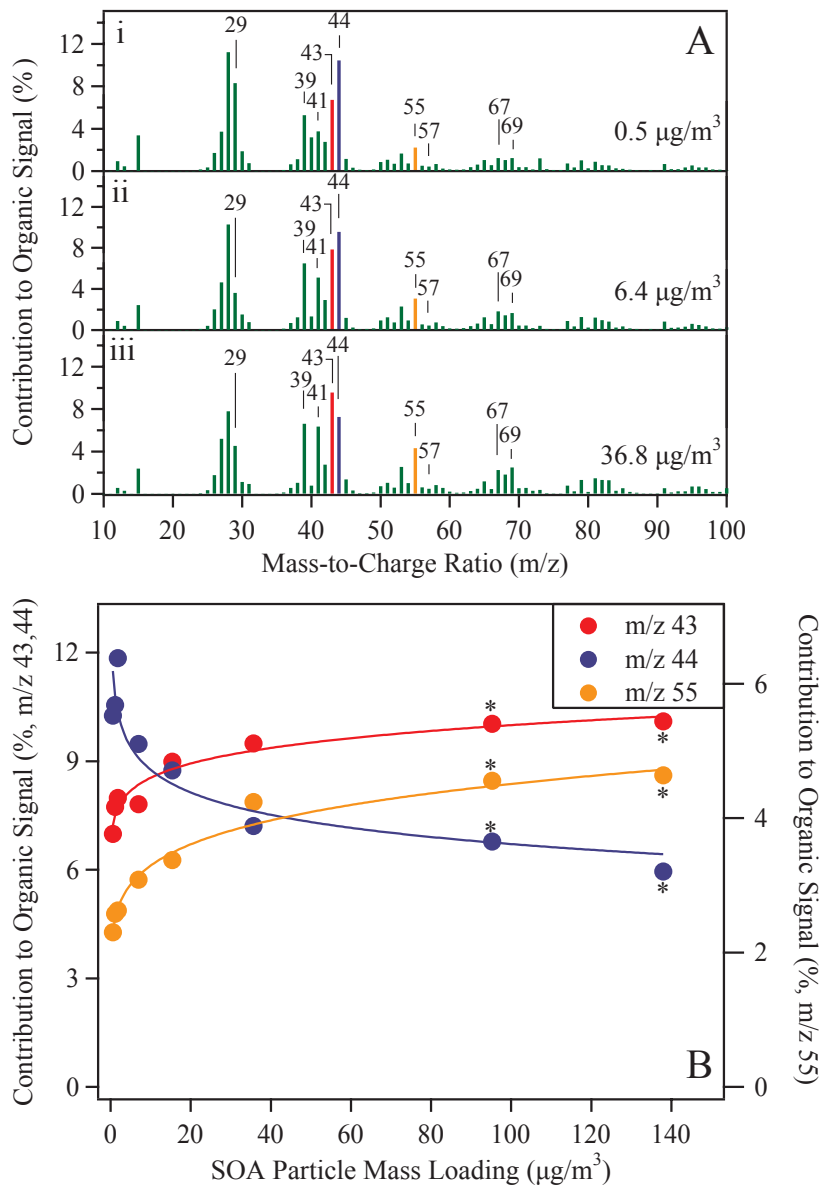

Fig. 1. (A) Representative organic-component mass spectra at unitmass resolution for SOA particles produced from the dark ozonolysis of $\alpha$-pinene. The spectra were collected at organic particle loadings of (i) $0.5 \mu \mathrm{g} / \mathrm{m}^{3}$, (ii) $6.4 \mu \mathrm{g} / \mathrm{m}^{3}$, and (iii) $36.8 \mu \mathrm{g} / \mathrm{m}^{3}$. Other reaction conditions were $25^{\circ} \mathrm{C}, 40 \% \mathrm{RH}$, dry $\left(\mathrm{NH}_{4}\right)_{2} \mathrm{SO}_{4}$ seed particles, 300 ppbv $\mathrm{O}_{3}, 3.4 \mathrm{~h}$ chamber residence time, and excess 1butanol. The signal intensity at each $\mathrm{m} / \mathrm{z}$, value represents its percentage contribution to the total organic signal intensity. (B) Percentage contribution of the unit-mass signal intensities at $\mathrm{m} / \mathrm{z} 43$, 44, and 55 to the total organic signal intensity (e.g., 43/org) for increasing organic particle mass loading. Asterisks indicate lower limits of the actual mass loadings because the particles that grew to diameters greater than $500 \mathrm{~nm}$ were not transmitted with $100 \%$ efficiency through the AMS lens. Lines are shown to guide the eye.

$\mathrm{H}_{\mathrm{x}} \mathrm{O}^{+}$fragments from organic species at $m / z 16,17$, and 18 were estimated as described in Aiken et al. (2008). During the course of an experiment, no significant changes in the organic mass spectra of the particles were observed once the chamber reached a steady state.

\section{Results and discussion}

\subsection{Low-resolution mass spectra}

Figure 1a shows the mass spectra at unit mass resolution (UMR) of $\alpha$-pinene SOA particles for loadings of $0.5,6.4$, and $36.8 \mu \mathrm{g} / \mathrm{m}^{3}$. The most intense peaks occur at $\mathrm{m} / \mathrm{z} 28$ $\left(\mathrm{CO}^{+}, \mathrm{C}_{2} \mathrm{H}_{4}^{+}\right), 29\left(\mathrm{CHO}^{+}, \mathrm{C}_{2} \mathrm{H}_{5}^{+}\right), 39\left(\mathrm{C}_{3} \mathrm{H}_{3}^{+}\right), 41\left(\mathrm{C}_{2} \mathrm{HO}^{+}\right.$, $\left.\mathrm{C}_{3} \mathrm{H}_{5}^{+}\right), 43\left(\mathrm{C}_{2} \mathrm{H}_{3} \mathrm{O}^{+}, \mathrm{C}_{3} \mathrm{H}_{7}^{+}\right), 44\left(\mathrm{CO}_{2}^{+}, \mathrm{C}_{2} \mathrm{H}_{4} \mathrm{O}^{+}\right)$, and 55 $\left(\mathrm{C}_{3} \mathrm{H}_{3} \mathrm{O}^{+}, \mathrm{C}_{4} \mathrm{H}_{7}^{+}\right)$. Inspection of panels $\mathrm{i}$ to iii shows that the percent contributions by the different $\mathrm{m} / \mathrm{z}$ signals vary with loading. The percent contributions of $\mathrm{m} / \mathrm{z} 43,44$, and 55 (e.g., 43/org) are shown in Fig. $1 \mathrm{~b}$ for decreasing loading. The contribution at $m / z, 43$ decreases from 10 to $7 \%$ as the loading drops from $>140$ to $0.5 \mu \mathrm{g} / \mathrm{m}^{3}$. In comparison, the contribution at $\mathrm{m} / \mathrm{z} 44$ increases from 6 to $12 \%$. The implication is that the ratio of the signal intensities at $\mathrm{m} / \mathrm{z} 44$ and 43, which is an indicator of the oxygen content of the particles (Fig. S1, see http://www.atmos-chem-phys.net/9/771/2009/ acp-9-771-2009-supplement.pdf), decreases for greater organic mass loadings. In agreement, the intensities at $\mathrm{m} / \mathrm{z} 55$, 57,67 , and 69 , which are typically associated with more reduced species and anti-correlate with the oxygen-to-carbon ratio (Fig. S1), increase for greater organic mass loadings.

For all $\mathrm{m} / \mathrm{z}$ values, the percent contributions by different $\mathrm{m} / \mathrm{z}$ values change monotonically with increasing loading. The relative changes are larger for low $\left(<15 \mu \mathrm{g} / \mathrm{m}^{3}\right)$ compared to high loadings (Fig. 1b). In light of this finding, extrapolation may be inappropriate for laboratory results that were obtained under conditions of relatively high loading (i.e., $>15 \mu \mathrm{g} / \mathrm{m}^{3}$ ) to modeling applications relevant to the atmosphere, for which loadings of 0.1 to $20 \mu \mathrm{g} / \mathrm{m}^{3}$ are typical.

Across all experimental conditions, 5 to $7 \%$ of the organic signal intensity occurs for $m / z>100$, with no systematic dependence on loading. These observations, however, do not rule out the possible presence of oligomers in the SOA particles because the combination of particle pyrolysis on the $600^{\circ} \mathrm{C}$ AMS heater and the subsequent electron-impact ionization results in extensive molecular fragmentation. For comparison, ambient OOA in Pittsburg has $3.6 \%$ of the signal beyond $\mathrm{m} / \mathrm{z} 100$ (Zhang et al., 2005b, c).

The mass spectra shown in Fig. 1a can be compared to several SOA particle mass spectra collected in other environmental chambers for the dark ozonolysis of $\alpha$-pinene (Bahreini et al., 2005; Alfarra et al., 2006; Song et al., 2007). The mass spectrum of panel iii is collected for a loading similar to those of the other chamber studies and is similar to the spectra reported therein. Specifically, the relative intensities of the major peaks (i.e., $m / z, 29,41,43,44,55$ and 57) are similar to those reported for the other chambers. Panels i and ii at lower loadings, however, present spectra unlike those published in the literature. These spectra at low loading show that the contribution by $\mathrm{m} / \mathrm{z}, 44$ exceeds that of $\mathrm{m} / \mathrm{z}$ 43 , thus implying that the organic mass at lower loading has an increased oxygen-to-carbon ratio compared to the higher 
loading of panel iii and of the other chamber studies. This increased oxygen-to-carbon ratio brings into better agreement the mass spectra observed in this chamber study at low loading with some of those collected in the ambient atmosphere (Sect. 4).

For further comparison, batch-mode experiments described in the literature demonstrated that the percent contribution at $m / z 44$ of SOA organic particle mass was higher during the initial as compared to the later stages of the experiments (Bahreini et al., 2005; Baltensperger et al., 2005; Zhang et al., 2006; Duplissy et al., 2008). The initial stages corresponded to conditions of low organic particle mass loading. A complication for the interpretation of the data, however, is that the gas-phase chemistry was simultaneously changing rapidly (cf. Fig. 6 of Shilling et al., 2008), and consequently the mass spectra were evolving in time and gas-particle equilibrium may not have been fully established. To overcome this difficulty in batch-mode experiments, Grieshop et al. (2007) first waited for the initial gasphase chemistry to come to completion for the dark ozonolysis of $\alpha$-pinene and then performed isothermal dilution experiments with clean air. Their results showed both that the gas-particle relaxation times from evaporation-condensation were longer than previously anticipated (e.g., tens of minutes rather than tens of seconds) and that the relative contribution of the 44/org signal measured at unit resolution by an AMS increased from ca. $4 \%$ to $6 \%$ as the SOA particle loading decreased for the range 500 to $100 \mu \mathrm{g} / \mathrm{m}^{3}$. For the present experiments, under the steady-state conditions of continuous-flow, the gas-phase product distribution calculated with the MCM was similar at all loadings (Table 1), and the mass spectra did not change during the course of an experiment. The relative contribution of the 44/org signal increased from 6 to $12 \%$ as SOA particle loading decreased for the range $>140$ to $0.5 \mu \mathrm{g} / \mathrm{m}^{3}$. The results of the experiments reported in the literature for batch mode and our findings obtained in continuous mode both affirm that SOA particles at low loadings are more oxygenated than at higher loadings.

\subsection{High-resolution mass spectra}

Ions having the same nominal $\mathrm{m} / \mathrm{z}$ value at unit-mass resolution can be separately identified and quantified in the highresolution mass spectra (McLafferty and Turecek, 1993; DeCarlo et al., 2006). Examples at nominal $\mathrm{m} / \mathrm{z} 43$ include $\mathrm{C}_{3} \mathrm{H}_{7}^{+}$(43.055) and $\mathrm{C}_{2} \mathrm{H}_{3} \mathrm{O}^{+}$(43.018). The HR-ToF-AMS has sufficient spectral resolution to distinguish $\mathrm{C}_{\mathrm{x}} \mathrm{H}_{\mathrm{y}}^{+}$from $\mathrm{C}_{\mathrm{x}} \mathrm{H}_{\mathrm{y}} \mathrm{O}_{\mathrm{z}}^{+}$and other ions at the same nominal $\mathrm{m} / \mathrm{z}$ value but having different numbers of $\mathrm{H}$ atoms (Fig. S3). Figure 2a shows the percent contribution of each type of ion for the same mass spectra as shown in Fig. 1a. The total signal intensity arising from the sum of each type of ion quantifies the so-called " $\mathrm{C}_{\mathrm{x}} \mathrm{H}_{\mathrm{y}}^{+}$" and " $\mathrm{C}_{\mathrm{x}} \mathrm{H}_{\mathrm{y}} \mathrm{O}_{\mathrm{z}}^{+}$" families (DeCarlo et al., 2006). Examination of Fig. 2a shows that, although the relative contribution of the $\mathrm{C}_{\mathrm{x}} \mathrm{H}_{\mathrm{y}} \mathrm{O}_{\mathrm{z}}^{+}$family at many $\mathrm{m} / \mathrm{z}$ values
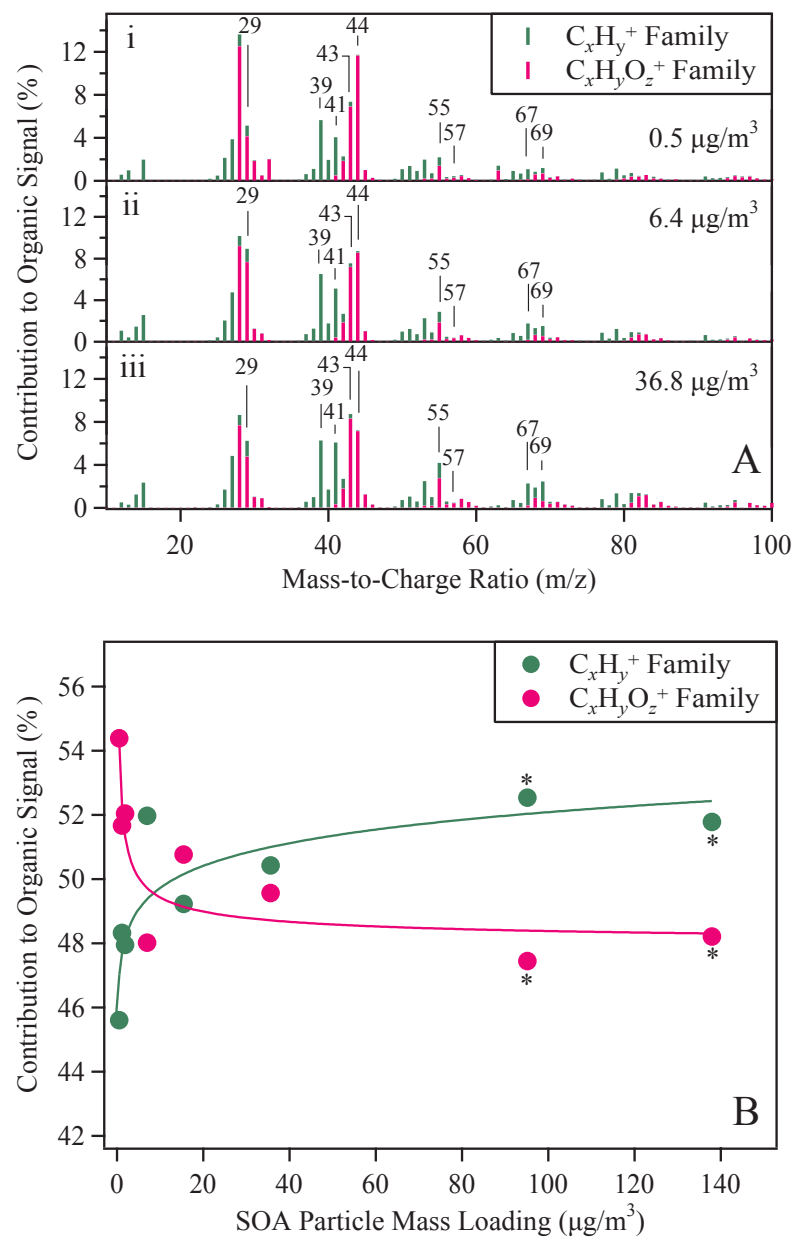

Fig. 2. (A) High-resolution mass spectra presented at unit mass resolution. The intensity bar at each $\mathrm{m} / \mathrm{z}$, value shows in green the relative contribution of fragments containing $\mathrm{C}$ and $\mathrm{H}$ (i.e., the $\mathrm{C}_{\mathrm{x}} \mathrm{H}_{\mathrm{y}}^{+}$ family) and in pink of fragments containing $\mathrm{C}, \mathrm{H}$, and $\mathrm{O}$ (i.e., the $\mathrm{C}_{\mathrm{x}} \mathrm{H}_{\mathrm{y}} \mathrm{O}_{\mathrm{z}}^{+}$family). Figure $\mathrm{S} 3$ shows an example of the deconvolution of the high-resolution mass spectra into the relative contributions by each family (DeCarlo et al., 2006). Reaction conditions and labels are as in Fig. 1, and the high-resolution spectra were collected contemporaneously with the data collection for Fig. 1. (B) Percent contribution of the $\mathrm{C}_{\mathrm{x}} \mathrm{H}_{\mathrm{y}}^{+}$and $\mathrm{C}_{\mathrm{x}} \mathrm{H}_{\mathrm{y}} \mathrm{O}_{\mathrm{z}}^{+}$families to the total organic signal for increasing organic particle mass loading. Lines are shown to guide the eye.

decreases for higher loadings as expected, some exceptions are apparent (e.g., $m / z 43,55$, and 57). The relative increases and decreases of specific peaks are complicated and reflect the combined results of changes in the individual fragmentation patterns of the changing mix of molecules in the particles as organic mass loading changes. Nevertheless, the sum across all species (as reflected in the " $\mathrm{C}_{\mathrm{x}} \mathrm{H}_{\mathrm{y}}^{+}$" and " $\mathrm{C}_{\mathrm{x}} \mathrm{H}_{\mathrm{y}} \mathrm{O}_{\mathrm{z}}^{+}$" families) provides overall insight into the changing oxidation state of the particles. 

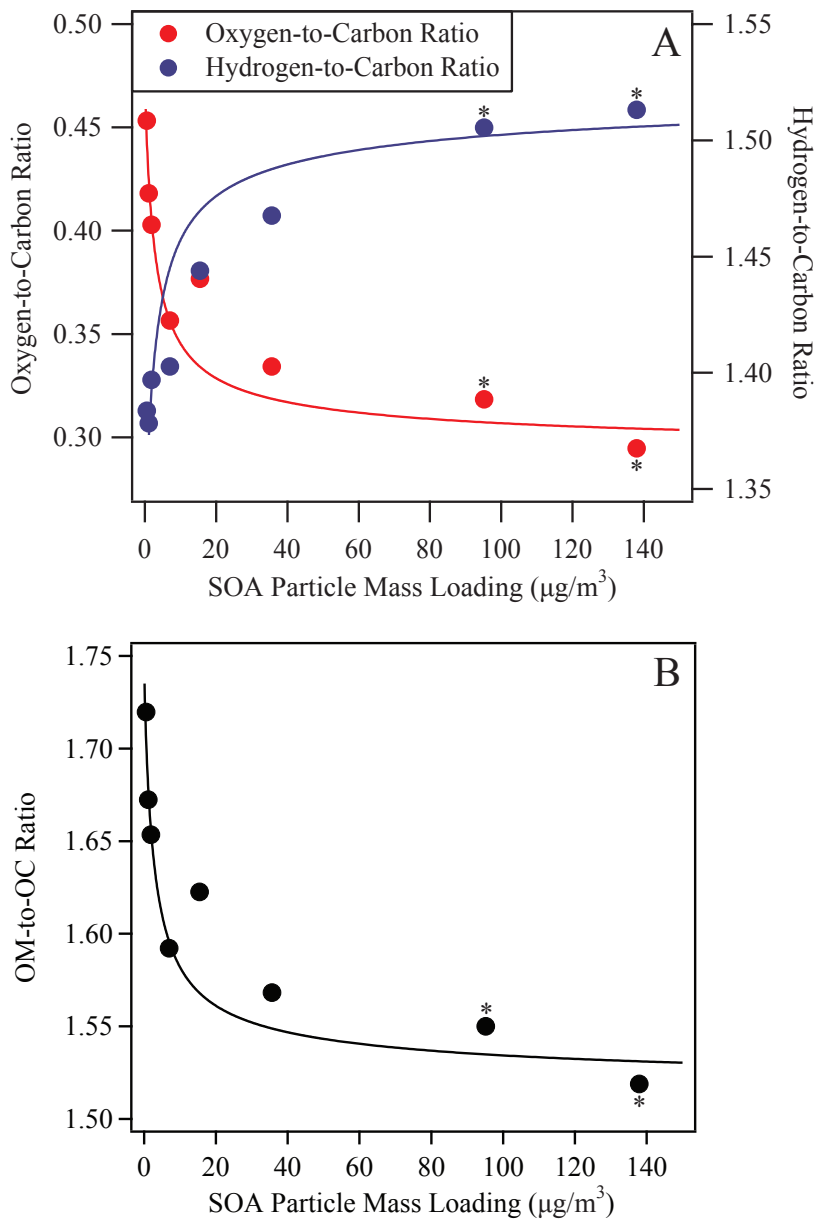

Fig. 3. (A) Oxygen-to-carbon and hydrogen-to-carbon atomic ratios for increasing organic particle mass loading. These ratios were obtained from the high-resolution mass spectra using the method of Aiken et al. (2007, 2008). Reaction conditions and labeling are as described for Fig. 1. Lines represent the parameterized atomic ratios according to Eqs. (1) and (2) and entries of Table 2. Accuracy of the measurements is approximately $\pm 30 \%$, with precision of approximately $5 \%$. (B) Ratio of the organic mass $(\mathrm{OM})$ to the organiccarbon mass (OC) determined from the AMS elemental analysis. The line is based on the parameterization of the oxygen-to-carbon and hydrogen-to-carbon atomic ratios.

Figure $2 b$ shows the relative contributions of the " $\mathrm{C}_{\mathrm{x}} \mathrm{H}_{\mathrm{y}}^{+}$" and " $\mathrm{C}_{\mathrm{x}} \mathrm{H}_{\mathrm{y}} \mathrm{O}_{\mathrm{z}}^{+}$" families for increasing mass loading. These high-resolution results, in agreement with the UMR results of Fig. 1b, show that the greatest variability in chemical composition occurs for low particle loadings $\left(<15 \mu \mathrm{g} / \mathrm{m}^{3}\right)$. Figure $2 b$ also shows that the organic material becomes less oxygenated for greater loadings, thus reinforcing the interpretation of Fig. 1 that the molecules partitioning into the particle phase at lower loadings are more oxygenated than those partitioning at higher loadings, as might be expected from structure-activity relationships of vapor pressure for organic molecules (Pankow and Asher, 2008).
Table 2. Four model products $i$ describing the partitioning of SOA molecules between the gas and particle phases for the dark ozonolysis of $\alpha$-pinene. Shown are the mass yield $\alpha_{i}$, the decadal volatility $C_{i}^{*}\left(\mu \mathrm{g} / \mathrm{m}^{3}\right)$, the atomic ratios $(\mathrm{O} / \mathrm{C})_{i}$ and $(\mathrm{H} / \mathrm{C})_{i}$, and the corresponding empirical formulas on a one-carbon basis. Determination of $\alpha_{i}$ and $C_{i}^{*}$ from the mass yield is described in Shilling et al. (2008). Donahue et al. (2006) describe the basis-set model of decadal volatility to parameterize yield data.

\begin{tabular}{lccccc}
\hline & $C_{i}^{*}\left(\mu \mathrm{g} / \mathrm{m}^{3}\right)$ & $\alpha_{i}$ & $(\mathrm{O} / \mathrm{C})_{i}$ & $(\mathrm{H} / \mathrm{C})_{i}$ & Empirical formula \\
\hline Product 1 & 0.1 & 0.080 & 0.48 & 1.32 & $\mathrm{C}_{1} \mathrm{H}_{1.32} \mathrm{O}_{0.48}$ \\
Product 2 & 1 & 0.019 & 0.39 & 1.36 & $\mathrm{C}_{1} \mathrm{H}_{1.36} \mathrm{O}_{0.39}$ \\
Product 3 & 10 & 0.180 & 0.24 & 1.57 & $\mathrm{C}_{1} \mathrm{H}_{1.57} \mathrm{O}_{0.24}$ \\
Product 4 & 100 & 0.030 & 0.14 & 1.76 & $\mathrm{C}_{1} \mathrm{H}_{1.76} \mathrm{O}_{0.14}$ \\
\hline
\end{tabular}

The oxygen-to-carbon (O/C) and hydrogen-to-carbon $(\mathrm{H} / \mathrm{C})$ atomic ratios can be calculated from an analysis of the signal intensities and elemental compositions of the $\mathrm{C}_{\mathrm{x}} \mathrm{H}_{\mathrm{y}}^{+}$ and $\mathrm{C}_{\mathrm{x}} \mathrm{H}_{\mathrm{y}} \mathrm{O}_{\mathrm{z}}^{+}$ions (Aiken et al., 2007, 2008). An experimentally determined calibration factor, which accounts for biases in ion fragmentation, is applied to the summed signals to obtain the reported $\mathrm{O} / \mathrm{C}$ and $\mathrm{H} / \mathrm{C}$ atomic ratios (Aiken et al., 2008). Figure 3 shows that the $\mathrm{O} / \mathrm{C}$ atomic ratio decreases from 0.45 to 0.38 as the particle loading increases from 0.5 to $15 \mu \mathrm{g} / \mathrm{m}^{3}$. The ratio changes more slowly for greater loadings, reaching a final value of 0.29 for the highest loadings. Conversely, the $\mathrm{H} / \mathrm{C}$ atomic ratio increases from 1.38 to 1.51 as the loading increases.

The $\mathrm{O} / \mathrm{C}$ atomic ratios determined in our study can be compared to other reports using the HR-ToF-AMS. Aiken et al. (2008) studied SOA prepared by the dark ozonolysis of $\alpha$-pinene for a peak mass loading of $500 \mu \mathrm{g} / \mathrm{m}^{3}$ and reported an $\mathrm{O} / \mathrm{C}$ ratio of 0.27 . This value is comparable to our value of 0.29 determined for a loading of $>140 \mu \mathrm{g} / \mathrm{m}^{3}$. Aiken et al. (2008) further reported O/C ratios of 0.27 to 0.43 for loadings of 50 to $100 \mu \mathrm{g} / \mathrm{m}^{3}$ for SOA particles produced in the chamber from other anthropogenic and biogenic precursors during full photochemistry (i.e., $\mathrm{NO}_{\mathrm{x}}, \mathrm{OH}$, and UV light). For ground and aircraft observations in Mexico City during MILAGRO, component mass spectra of HOA, OOAI, and OOA-II were obtained by positive matrix multifactor analysis (Aiken et al., 2008). On the ground, HOA, OOA-I, and OOA-II had O/C ratios of $0.10,0.83$, and 0.52 , respectively, and the corresponding values from the aircraft observations were $0.06,1.02$, and 0.64 . Our $\mathrm{O} / \mathrm{C}$ ratio measurements, ranging from 0.29 to 0.45 , best overlap with OOAII. This component has been ascribed to "fresh" SOA particles and therefore might be considered comparable to our study in an environmental chamber, although biogenic precursors were used by us whereas Mexico City represents a heavily polluted, anthropogenically-influenced airshed. In February-March 2008, preliminary analysis of the O/C ratio of organic particles in the wet season of the Amazon showed a campaign average of ca. 0.6 for organic particle 
mass loadings of ca. $1 \mu \mathrm{g} / \mathrm{m}^{3}$ (Q. Chen et al., 2009 ${ }^{1}$ ). This organic material, perhaps made heavily from isoprene oxidation products, is somewhat more oxidized than the SOA particles prepared in this study by the dark ozonolysis of $\alpha$ pinene (i.e., $\mathrm{O} / \mathrm{C}$ ratio of 0.40 to 0.45 for 0.5 to $2 \mu \mathrm{g} / \mathrm{m}^{3}$ ).

The ratio of particle organic mass (OM) to particle organic-carbon mass (OC) can be calculated from the measured $\mathrm{O} / \mathrm{C}$ and $\mathrm{H} / \mathrm{C}$ ratios, as follows: $\mathrm{OM} / \mathrm{OC}=[(16 \times \mathrm{O} / \mathrm{C})+(1 \times \mathrm{H} / \mathrm{C})+12] / 12$. The $\mathrm{OM} / \mathrm{OC}$ ratio is used in regard to atmospheric measurements to estimate OM mass loadings when only measurements of OC mass loadings are available (White and Roberts, 1977). Figure $3 b$ shows that the OM/OC ratio calculated in this study increases from 1.52 to 1.72 as the particle loading decreases from $>140$ to $0.5 \mu \mathrm{g} / \mathrm{m}^{3}$. These values are higher than a widely used reference value of 1.4 that was originally determined for organic particles in the Los Angeles area (White and Roberts, 1977). The values are lower than the recommended value of 2.1 for nonurban locations (Turpin and Lim, 2001; Pang et al., 2006) and the values measured in Mexico City for fresh and aged urban SOA particles (1.85-2.45, Aiken et al., 2008). Our values are similar, however, to the recommended OM/OC of 1.6 for urban aerosol particles (Turpin and Lim, 2001; Pang et al., 2006) as well as to OM/OC values reported for SOA particles produced in several other chamber experiments (Aiken et al., 2008).

\subsection{Chemically-resolved partitioning}

A view on chemically-resolved gas-particle partitioning can be obtained from the high-resolution mass spectra. Figure 4 shows a basis-set fit using decadal volatility for four model products (Donahue et al., 2006). At each loading, the overall bar height shows the mass yield predicted from the basisset fit of the yield data (Shilling et al., 2008). An individual bar is color-coded by the relative contribution of each model product to the yield. The empirical formulas of the basis-set products normalized to one carbon atom are provided in the legend.

The empirical formulas $(\mathrm{O} / \mathrm{C})_{i}$ and $(\mathrm{O} / \mathrm{C})_{i}$ of the basis-set products $i$ are related to $(\mathrm{O} / \mathrm{C})_{j}$ and $(\mathrm{H} / \mathrm{C})_{j}$ measured at each mass loading $j$, as follows.

$$
(\mathrm{O} / \mathrm{C})_{j}=\frac{\sum_{i} f_{i, j} \lambda_{i}(\mathrm{O} / \mathrm{C})_{i}}{\sum_{i} f_{i, j} \lambda_{i}},(\mathrm{H} / \mathrm{C})_{j}=\frac{\sum_{i} f_{i, j} \lambda_{i}(\mathrm{H} / \mathrm{C})_{i}}{\sum_{i} f_{i, j} \lambda_{i}}
$$

where $\lambda_{i}$ is the carbon molinity, defined as the moles of carbon of product $i$ per kilogram of product $i$. In the case of SOA particles of composition $\mathrm{C}_{\mathrm{x}} \mathrm{H}_{\mathrm{y}} \mathrm{O}_{\mathrm{z}}$ and no other elements, we can write $\lambda_{i}=1000 /\left(12+(\mathrm{H} / \mathrm{C})_{i}+16(\mathrm{O} / \mathrm{C})_{i}\right)$.

\footnotetext{
${ }^{1}$ Chen, Q., Martin, S. T., et al.: Results in preparation from AMAZE-08 campaign, Atmos. Chem. Phys. Discuss., 2009.
}

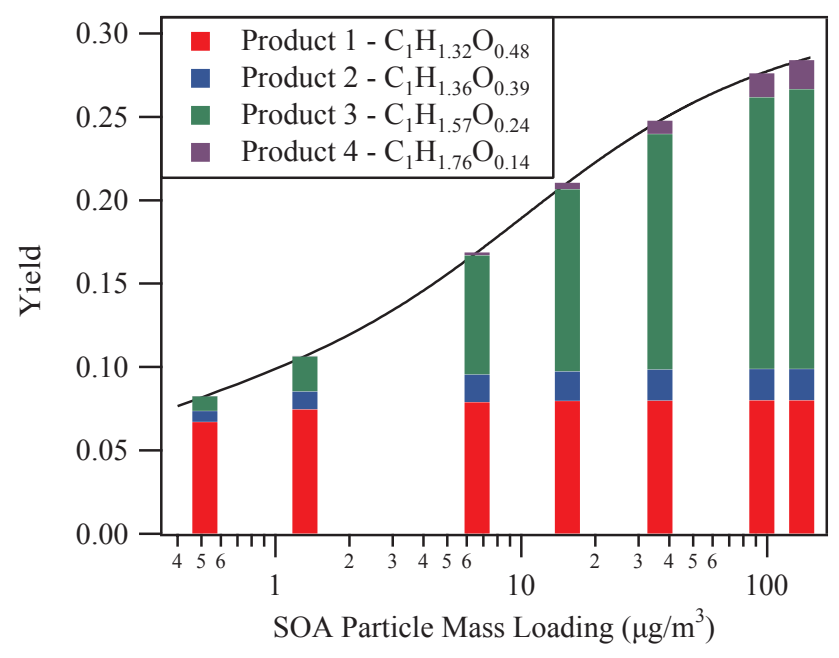

Fig. 4. Chemically resolved SOA particle mass yield for increasing organic particle mass loading. The bar at each of these mass loading shows the relative contribution of the four basis-set products. The inset shows the chemical formula of each of these products on a one-carbon basis (i.e., empirical formula). Table 2 summarizes the parameters of the four basis-set products, including their decadal volatility.

The mass fraction $f_{i, j}$ is obtained from the four-product basis-set parameterization of yield, as follows. The particlephase partial mass yield $\xi_{i, j}$ of product $i$ at loading $C_{j}$ $\left(\mu \mathrm{g} / \mathrm{m}^{3}\right)$ is given by $\xi_{i, j}=\alpha_{i}\left(1+C_{i}^{*} / C_{j}\right)^{-1}$, where $C_{i}^{*} \in$ $\left\{10^{-1}, 10^{0}, 10^{1}, 10^{2} \mu \mathrm{g} / \mathrm{m}^{3}\right\}$ and $\alpha_{i}$ is the ozonolysis mass yield (gas + particle) of product $i$ (Table 2). The observed yield $Y_{j}$ is then given by $Y_{j}=\Sigma_{i} \xi_{i, j}$. At a loading $C_{j}$, the relative concentration of product $i$ in the particle-phase on a mass-fraction basis then follows:

$f_{i, j}=\xi_{i, j}\left(\sum_{i=1}^{4} \xi_{i, j}\right)^{-1}$

For fixed mass loading, the relative bar heights in Fig. 4 correspond to the relative values of $f_{i}$.

Equation (1) thus constitutes a system of $2 j$ (14) simultaneous equations and $2 i$ (specificially, $2 i=8$ ) variables. The empirical formulas shown in Table 2 result from their solution, when subject to the constraints $0<(\mathrm{O} / \mathrm{C})_{i}<1$ and $1<(\mathrm{H} / \mathrm{C})_{i}<2$. From low to high volatility, the empirical formulas are as follows: $\mathrm{C}_{1} \mathrm{H}_{1.32} \mathrm{O}_{0.48}, \mathrm{C}_{1} \mathrm{H}_{1.36} \mathrm{O}_{0.39}$, $\mathrm{C}_{1} \mathrm{H}_{1.57} \mathrm{O}_{0.24}$, and $\mathrm{C}_{1} \mathrm{H}_{1.76} \mathrm{O}_{0.14}$. Comparisons between measurements and the optimized solution of Eq. (1) are shown by the data points and the solid lines in Fig. 3, respectively.

The $\mathrm{O} / \mathrm{C}$ and $\mathrm{H} / \mathrm{C}$ atomic ratios of the basis-set products can be compared to those expected for the major particle-phase molecular products identified for the dark ozonolysis of $\alpha$-pinene (Jang and Kamens, 1999; Yu et al., 1999). Those products include norpinic acid and its 


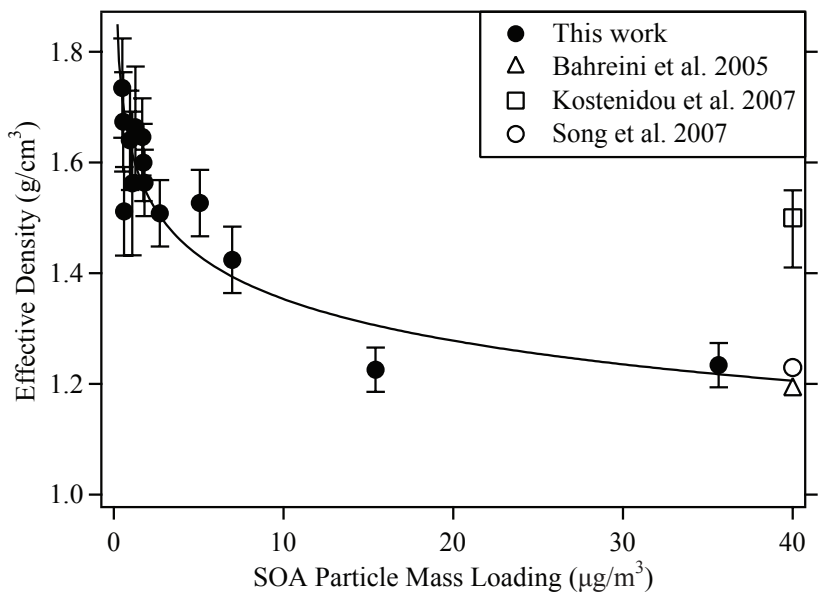

Fig. 5. Effective density of the SOA organic particle mass for increasing loading. Density and effective density equal one another for spherical particles. Effective density was calculated from the AMS-determined vacuum aerodynamic diameter and the SMPSdetermined electric mobility diameter (DeCarlo et al., 2004; Katrib et al., 2005). The calculation included a volume-weighted correction for the ammonium sulfate seed. See Shilling et al. (2008) for further information. Reaction conditions were as described for Fig. 1. Densities reported in the literature for mass loadings of 5 to $220 \mu \mathrm{g} / \mathrm{m}^{3}$ are shown for comparison (Bahreini et al., 2005; Kostenidou et al., 2007; Song et al., 2007). The studies in literature do not report the variation of density with organic mass loading, and the literature points are therefore placed at the righthand edge of the $\mathrm{x}$-axis. The bar on the measurement of Kostenidou et al. (2007) shows the range of values reported therein.

isomers $\left(\mathrm{C}_{8} \mathrm{H}_{12} \mathrm{O}_{4}, \mathrm{H} / \mathrm{C}: 1.5, \mathrm{O} / \mathrm{C}: 0.5\right)$, pinic acid $\left(\mathrm{C}_{9} \mathrm{H}_{14} \mathrm{O}_{4}\right.$, $\mathrm{H} / \mathrm{C}: 1.56$, O/C:0.44), pinonic acid $\left(\mathrm{C}_{10} \mathrm{H}_{16} \mathrm{O}_{3}, \mathrm{H} / \mathrm{C}: 1.6\right.$, $\mathrm{O} / \mathrm{C}: 0.33)$, hydroxy pinonaldehydes $\left(\mathrm{C}_{10} \mathrm{H}_{16} \mathrm{O}_{3}, \mathrm{H} / \mathrm{C}: 1.6\right.$, $\mathrm{O} / \mathrm{C}: 0.33)$, norpinaldehyde $\left(\mathrm{C}_{9} \mathrm{H}_{14} \mathrm{O}_{2}, \mathrm{H} / \mathrm{C}: 1.56, \mathrm{O} / \mathrm{C}: 0.22\right)$, and pinonaldehyde $\left(\mathrm{C}_{10} \mathrm{H}_{16} \mathrm{O}_{2}, \mathrm{H} / \mathrm{C}: 1.6, \mathrm{O} / \mathrm{C}: 0.2\right)$. The $\mathrm{O} / \mathrm{C}$ atomic ratios of these major products therefore range from 0.20 to 0.50 compared to 0.14 to 0.48 for the four basis-set products. The $\mathrm{O} / \mathrm{C}$ ratios of the basis-set products therefore span the expected range of $\mathrm{O} / \mathrm{C}$ ratios based on the experimentally identified particle-phase molecular products.

In comparison, the $\mathrm{H} / \mathrm{C}$ atomic ratios of the products identified in literature range from 1.5 to 1.6 compared to 1.32 to 1.75 for the four basis-set products. The lowest volatility products (viz. $i=1$ and 2 of Table 2) are therefore depleted in hydrogen compared to the identified particle-phase molecular products. An explanation could be the formation of longer carbon-chain products, such as oligomers (Gao et al., 2004; Kalberer et al., 2004; Tolocka et al., 2004), organic peroxides and adducts of stabilized Criegee intermediates (Docherty et al., 2005), or other unidentified products that shift the H/C ratio without greatly affecting the $\mathrm{O} / \mathrm{C}$ ratio.

The empirical formulas of Table 2 are on a one-carbon basis, but many of the known particle-phase molecular prod- ucts (such as norpinic acid, pinic acid, pinonic acid, hydroxy pinonaldehydes, norpinaldehyde, and pinonaldehyde) are $\mathrm{C}_{8}$ to $\mathrm{C}_{10}$ compounds. For purpose of development, we can then assume that the empirical formulas of Table 2 correspond to the molecular formulas on a $\mathrm{C}_{9}$ basis: $\mathrm{C}_{9} \mathrm{H}_{11.9} \mathrm{O}_{4.3}$, $\mathrm{C}_{9} \mathrm{H}_{12.2} \mathrm{O}_{3.5}, \mathrm{C}_{9} \mathrm{H}_{14.1} \mathrm{O}_{2.2}$, and $\mathrm{C}_{9} \mathrm{H}_{15.8} \mathrm{O}_{1.3}$. On this basis, each product of decadal volatility differs from the next by approximately one oxygen atom. In agreement, the groupcontribution method estimates that the addition of one carbonyl group reduces the vapor pressure of an aliphatic compound by a decade (Pankow and Asher, 2008).

The vapor pressures of the known particle-phase molecular products can be compared to the decadal vapor pressures used in the basis-set fitting. Pinic acid, for example, has a vapor pressure of $2.4 \mu \mathrm{g} / \mathrm{m}^{3}$ and is the least volatile monomer product identified in the literature (Bilde and Pandis, 2001). This vapor pressure is 24 times greater than $0.1 \mu \mathrm{g} / \mathrm{m}^{3}$ of $C_{1}^{*}$, implying that unidentified products with lower volatility than pinic acid compose a significant fraction of the particle-phase mass at the lowest loadings. Some possible products could include organic peroxides and adducts of stabilized Criegee intermediates, multimers (e.g., dimmers and longer chain oligomers), or other as-yet unidentified products (Gao et al., 2004; Kalberer et al., 2004; Tolocka et al., 2004; Docherty et al., 2005). Formation of these species through routes not involving elimination of oxygen is consistent with the observed $\mathrm{O} / \mathrm{C}$ atomic ratios (vida supra). In further comparison, the vapor pressure of cis-pinonic acid $\left(5.2 \mu \mathrm{g} / \mathrm{m}^{3}\right.$; Bilde and Pandis, 2001) is in the approximate range of product 3 $\left(C_{3}^{*}=10 \mu \mathrm{g} / \mathrm{m}^{3}\right)$. cis-Pinonic acid has $\mathrm{O} / \mathrm{C}$ and $\mathrm{H} / \mathrm{C}$ atomic ratios similar to those of product 3 . Full agreement, however, is not found in all comparisons. Although the $\mathrm{O} / \mathrm{C}$ and $\mathrm{H} / \mathrm{C}$ atomic ratios of pinonaldehyde agree well with those of product 4 , the vapor pressure of the former $\left(3.5 \times 10^{5} \mu \mathrm{g} / \mathrm{m}^{3}\right.$; Hallquist et al., 1997) is 1000-fold higher than that of the latter $\left(C_{4}^{*}=100 \mu \mathrm{g} / \mathrm{m}^{3}\right)$.

\subsection{Density}

Given that the organic material of the SOA particles is increasingly oxygenated for lower loadings, a reasonable expectation is that the organic density should likewise increase. Figure 5 shows that the effective organic density is $1.73 \pm 0.13 \mathrm{~g} / \mathrm{cm}^{3}$ for a loading of $0.46 \mu \mathrm{g} / \mathrm{m}^{3}$ but decreases to $1.42 \pm 0.06 \mathrm{~g} / \mathrm{cm}^{3}$ for a loading of $7 \mu \mathrm{g} / \mathrm{m}^{3}$ and to $1.23 \pm 0.04 \mathrm{~g} / \mathrm{cm}^{3}$ for loadings of $15.9 \mu \mathrm{g} / \mathrm{m}^{3}$ and greater (DeCarlo et al., 2004; Katrib et al., 2005). Densities for higher loadings could not be determined from our measurements because the mode of the particle size distribution exceeded the limit of $495 \mathrm{~nm}$ for our operating conditions of the SMPS. The relatively high uncertainty of \pm 0.13 for the measured density of $1.73 \mathrm{~g} / \mathrm{cm}^{3}$ at $0.46 \mu \mathrm{g} / \mathrm{m}^{3}$ occurs because the relatively high inorganic mass loading of seed particles compared to the low organic mass loading affects the accuracy of the analysis. Other workers report densities of 
1.19 to $1.52 \mathrm{~g} / \mathrm{cm}^{3}$ for organic loadings of 5 to $220 \mu \mathrm{g} / \mathrm{m}^{3}$ for SOA particles formed by the dark ozonolysis of $\alpha$-pinene (Bahreini et al., 2005; Kostenidou et al., 2007; Song et al., 2007), in agreement with the densities determined in this study at loadings greater than $7 \mu \mathrm{g} / \mathrm{m}^{3}$.

In the laboratory and the field, accurate measurements of organic density are essential for conversion of SMPS measurements of a volume concentration to a mass loading. In addition, parameterizations employed in chemical transport models for particle mass yield from SOA production are often normalized to an organic density of $1.0 \mathrm{~g} / \mathrm{cm}^{3}$ (Chung and Seinfeld, 2002), potentially leading to an underestimate of the organic particle mass loading.

\section{Conclusions and atmospheric implications}

The chemical composition of SOA particles produced from the dark ozonolysis of $\alpha$-pinene was characterized for increasing organic particle mass loading. The gas-phase chemistry and the aging of the aerosol were constant across experiments, thus isolating the effects of gas-particle partitioning from other processes. The particle mass spectra depended on the organic loading, and an analysis of the high-resolution mass spectra showed that the organic particle mass became increasingly oxygenated for lower loadings. The changes in the particle composition were most sensitive to loading from 0.5 to $15 \mu \mathrm{g} / \mathrm{m}^{3}$, with smaller changes in composition for loadings from 15 to $>140 \mu \mathrm{g} / \mathrm{m}^{3}$. The chemical composition for variable loading, expressed as $\mathrm{O} / \mathrm{C}$ and $\mathrm{H} / \mathrm{C}$ atomic ratios, was accurately parameterized with four basis-set products of decadal volatility.

The increase in the $\mathrm{O} / \mathrm{C}$ atomic ratio for lower mass loadings and the corresponding decrease in the $\mathrm{H} / \mathrm{C}$ ratio can be explained in large part by the variable partitioning of semivolatile molecules into the particle phase. In favor of this explanation compared to others, such as particle-phase reactive chemistry, is that the modeled gas-phase chemistry (Table 1) and the residence time in the chamber are nearly identical in all experiments. At low loadings (implying low vapor pressures), the increase of the $\mathrm{O} / \mathrm{C}$ ratio is consistent with the expected structure-activity correlation between increases in oxygen-bearing functional groups and reductions in vapor pressure (Pankow and Asher, 2008). Nevertheless, the possibilities of second-order gas-phase reactions or heterogeneous chemistry cannot be completely excluded as contributors. To consider the possibility of changed gas-phase chemistry in more detail, we use the MCM model v3.1 to investigate possible differences in the gas-phase chemistry due to second-order radical reactions (Saunders et al., 2003). Table 1 shows the product distribution for simulations run at $0.9,6.7$, and $91.1 \mathrm{ppbv}$ of $\alpha$-pinene. The relative distributions of stable products, such as pinic acid, hydroxy pinic acid, pinonaldehyde, and norpinaldehyde, are similar among the three simulations. Although there is some variation in the

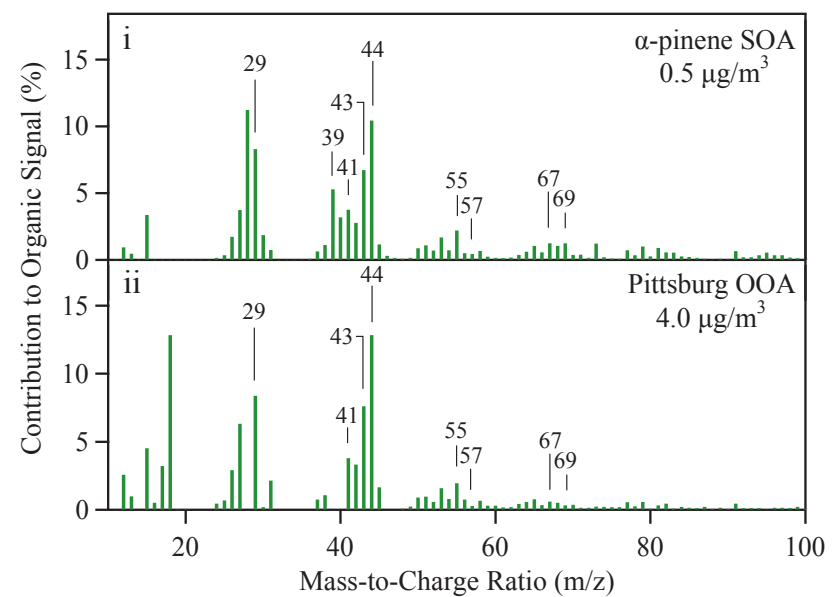

Fig. 6. Comparison of (i) the mass spectrum collected in the Harvard Environmental Chamber for a loading of $0.5 \mu \mathrm{g} / \mathrm{m}^{3}$ (cf. Fig. 1) to (ii) the OOA-component mass spectrum obtained by multifactor analysis of ambient observations in Pittsburgh, USA, during September 2002 (Zhang et al., 2005b). The organic mass loading averaged $4 \mu \mathrm{g} / \mathrm{m}^{3}$ at that time.

relative distribution of the peroxy radicals and the peroxides (with the $\mathrm{C}_{10}$ species having the largest variability), the variation appears too small to explain the measured changes in the chemical composition of the particles with loading.

The mass spectra obtained at low loadings in this study compare favorably to those observed at times in the ambient environment. Figure 6 shows a comparison of the spectrum collected at $0.5 \mu \mathrm{g} / \mathrm{m}^{3}$ to a representative OOA spectrum collected in Pittsburgh, USA, in September 2002 by Zhang et al. (2005b), during which time the average organic mass loading was $4 \mu \mathrm{g} / \mathrm{m}^{3}$. The relative heights of the prominent peaks are similar in the two spectra, in particular the ratio of the signal intensities at $\mathrm{m} / \mathrm{z}, 43$ and 44 . This ratio is an indicator of oxidation state (cf. Figs. S1, 2).

Figure 6 shows that the mass spectra collected in a laboratory environmental chamber for a biogenic precursor can be similar to those collected for ambient particles provided that laboratory measurements are carried out at mass loadings similar to those occurring in the atmosphere. The implication is that the electron-impact fragmentation patterns of the organic material in the two types of particles are similar, suggesting that the relative distributions of the organic functional groups are also similar. Nevertheless, within this similarity there are undoubtedly important differences that are not revealed by the comparison shown in Fig. 6 because of the myriad molecular assemblies possible from similar distributions of functional groups. Such different assemblies can be expected on the basis of the large number of VOC precursors involved in atmospheric SOA production compared to the single precursor employed in this study. Regarding anthropogenic precursors, Bahreini et al. (2005) and Robinson et al. (2007) showed that the mass spectra of SOA 
particles generated in an environmental chamber also can be similar to atmospheric observations. When taken together, the implication of those studies and ours is that the differences in the AMS UMR spectra are not large for SOA particles generated from anthropogenic and biogenic precursors. Therefore, in a regulatory context the attribution from mass spectra alone (e.g., by factor analysis) of biogenic compared to anthropogenic SOA particle mass and hence source controls must be approached cautiously (Zhang et al., 2005a, b; Marcolli et al., 2006; Lanz et al., 2007, 2008; Ulbrich et al., 2008). In particular, the library mass spectra to which results from factor analysis are compared must be collected under conditions similar to those occurring in the atmosphere.

The overall results and method of analysis of this study provide a chemically resolved picture of SOA partitioning. The findings should have future utility in the interpretation of field data and guiding regulatory development. Moreover, the empirical formulas can be compared to classically identified particle-phase products as an overall constraint on chemical closure, both for field and chamber measurements. In the future, chemical transport models of SOA formation and aging may be capable of including chemically resolved information (based on the laboratory findings) for further comparison to atmospheric measurements.

Acknowledgements. This material is based upon work supported by the National Science Foundation under Grant No. ATM-0513463. The development of the method for quantifying O/C and H/C was supported by NSF grant ATM-0449815 and EPA grant STAR-RD83216101-0. SMK and PFD acknowledge support from the EPA STAR fellowship program. TR acknowledges support from the Danish Agency for Science Technology and Innovation under Grant No. 272-06-0318. QC and ACA acknowledge support from the NASA ESS fellowship program. This paper has not been reviewed by any funding agency and thus any opinions, findings, and conclusions or recommendations expressed in this material are those of the authors and do not necessarily reflect the views of a funding agency.

Edited by: V. F. McNeill

\section{References}

Aiken, A. C., DeCarlo, P. F., and Jimenez, J. L.: Elemental analysis of organic species with electron ionization high-resolution mass spectrometry, Anal. Chem., 79, 8350-8358, 2007.

Aiken, A. C., DeCarlo, P. F., Kroll, J. H., Worsnop, D. R., Huffman, J. A., Cocherty, K., Ulbrich, I. M., Mohr, C., Kimmel, J. R., Sueper, D., Zhang, Q., Sun, Y., Trimborn, A., Northway, M., Ziemann, P. J., Canagaratna, M. R., Alfarra, R., Prevot, A. S. H., Dommen, J., Duplissy, J., Metzger, A., Baltensperger, U., and Jimenez, J. L.: O/C and OM/OC ratios of primary, secondary, and ambient organic aerosols with high resolution time-of-flight aerosol mass spectrometry, Environ. Sci. Technol., 42, 44784485, 2008.

Alfarra, M. R., Paulsen, D., Gysel, M., Garforth, A. A., Dommen, J., Prévôt, A. S. H., Worsnop, D. R., Baltensperger, U., and Coe, H.: A mass spectrometric study of secondary organic aerosols formed from the photooxidation of anthropogenic and biogenic precursors in a reaction chamber, Atmos. Chem. Phys., 6, 52795293, 2006, http://www.atmos-chem-phys.net/6/5279/2006/.

Allan, J. D., Coe, H., Bower, K. N., Alfarra, M. R., Delia, A. E., Jimenez, J. L., Middlebrook, A. M., Drewnick, F., Onasch, T. B., Canagaratna, M. R., Jayne, J. T., and Worsnop, D. R.: Technical note: Extraction of chemically resolved mass spectra from Aerodyne aerosol mass spectrometer data, J. Aerosol Sci., 35, 909-922, 2004.

Bahreini, R., Keywood, M. D., Ng, N. L., Varutbangkul, V., Gao, S., Flagan, R. C., Seinfeld, J. H., Worsnop, D. R., and Jimenez, J. L.: Measurement of secondary organic aerosol from oxidation of cycloalkenes, terpenes, and m-xylene using an Aerodyne aerosol mass spectrometer, Environ. Sci. Technol., 39, 5674-5688, 2005.

Baltensperger, U., Kalberer, M., Dommen, J., Paulsen, D., Alfarra, M. R., Coe, H., Fisseha, R., Gascho, A., Gysel, M., Nyeki, S., Sax, M., Steinbacher, M., Prevot, A. S. H., Sjogren, S., Weingartner, E., and Zenobi, R.: Secondary organic aerosols from anthropogenic and biogenic precursors, Faraday Discuss., 130, 265-278, 2005.

Bilde, M. and Pandis, S. N.: Evaporation rates and vapor pressures of individual aerosol species formed in the atmospheric oxidation of alpha- and beta-pinene, Environ. Sci. Technol., 35, 3344 3349, 2001.

Bowman, F. M. and Karamalegos, A. M.: Estimated effects of composition on secondary organic aerosol mass concentrations, Environ. Sci. Technol., 36, 2701-2707, 2002.

Canagaratna, M. R., Jayne, J. T., Jimenez, J. L., Allan, J. D., Alfarra, M. R., Zhang, Q., Onasch, T. B., Drewnick, F., Coe, H., Middlebrook, A., Delia, A., Williams, L. R., Trimborn, A. M., Northway, M. J., DeCarlo, P. F., Kolb, C. E., Davidovits, P., and Worsnop, D. R.: Chemical and microphysical characterization of ambient aerosol with the Aerodyne aerosol mass spectrometer, Mass. Spectrom. Rev., 26, 185-222, 2007.

Chung, S. H. and Seinfeld, J. H.: Global distribution and climate forcing of carbonaceous aerosols, J. Geophys. Res., 107, 4407, doi:10.1029/2001JD001397, 2002.

DeCarlo, P., Slowik, J., Worsnop, D., Davidovits, P., and Jimenez, J.: Particle morphology and density characterization by combined mobility and aerodynamic diameter measurements, Part 1: Theory, Aerosol Sci. Tech., 38, 1185-1205, 2004.

DeCarlo, P. F., Kimmel, J. R., Trimborn, A., Jayne, J. T., Aiken, A. C., Gonin, M., Fuhrer, K., Horvath, T., Docherty, K. S., Worsnop, D. R., and Jimenez, J. L.: A field-deployable high-resolution time-of-flight aerosol mass spectrometer, Anal. Chem., 78, 8281-8289, 2006.

Docherty, K. S., Wu, W., Lim, Y. B., and Ziemann, P. J.: Contributions of organic peroxides to secondary aerosol formed from reaction of monoterpenes with $\mathrm{O}_{3}$, Environ. Sci. Technol., 39, 4049-4059, 2005.

Donahue, N. M., Robinson, A. L., Stanier, C. O., and Pandis, S. N.: The coupled partitioning, dilution, and chemical aging of semivolatile organics, Environ. Sci. Technol., 40, 2635-2643, 2006.

Duplissy, J., Gysel, M., Alfarra, M. R., Dommen, J., Metzger, A., Prevot, A. S. H., Weingartner, E., Laaksonen, A., Raatikainen, T., Good, N., Turner, S. F., McFiggans, G., and Baltensperger, U.: The cloud forming potential of secondary organic aerosol under near atmospheric conditions, Geophys. Res. Lett., 35, L03818, 
doi:10.1029/2007GL031075, 2008.

Gao, S., Keywood, M., Ng, N. L., Surratt, J., Varutbangkul, V., Bahreini, R., Flagan, R. C., and Seinfeld, J. H.: Low-molecularweight and oligomeric components in secondary organic aerosol from the ozonolysis of cycloalkenes and alpha-pinene, J. Phys. Chem. A, 108, 10147-10164, 2004.

Grieshop, A. P., Donahue, N. M., and Robinson, A. L.: Is the gas-particle partitioning in alpha-pinene secondary organic aerosol reversible?, Geophys. Res. Lett., 34, L14810, doi:10.1029/2007GL029987, 2007.

Hallquist, M., Wangberg, I., and Ljungstrom, E.: Atmospheric fate of carbonyl oxidation products originating from $\alpha$-pinene and $\delta^{3}$ carene: Determination of rate of reaction with $\mathrm{OH}$ and $\mathrm{NO}_{3}$ radicals, UV absorption cross sections, and vapor pressures, Environ. Sci. Technol., 31, 3166-3172, 1997.

Heald, C. L., Jacob, D. J., Park, R. J., Russell, L. M., Huebert, B. J., Seinfeld, J. H., Liao, H., and Weber, R. J.: A large organic aerosol source in the free troposphere missing from current models, Geophys. Res. Lett., 32, L18809, doi:10.1029/2005GL023831, 2005.

Jang, M. and Kamens, R. M.: Newly characterized products and composition of secondary aerosols from the reaction of $\alpha$-pinene with ozone, Atmos. Environ., 33, 459-474, 1999.

Jayne, J. T., Leard, D. C., Zhang, X., Davidovits, P., Smith, K. A., Kolb, C. E., and Worsnop, D. R.: Development of an aerosol mass spectrometer for size and composition analysis of submicron particles, Aerosol Sci. Tech., 33, 49-70, 2000.

Jenkin, M. E.: Modelling the formation and composition of secondary organic aerosol from $\alpha$ - and $\beta$-pinene ozonolysis using MCM v3, Atmos. Chem. Phys., 4, 1741-1757, 2004, http://www.atmos-chem-phys.net/4/1741/2004/.

Jimenez, J. L., Shi, Q., Kolb, C. E., Worsnop, D. R., Yourshaw, I., Seinfeld, J. H., Flagan, R. C., Zhang, X., Smith, K. A., Morris, J. W., and Davidovits, P.: Ambient aerosol sampling using the Aerodyne aerosol mass spectrometer, J. Geophys. Res., 108, 8425, 10.1029/2001JD001213, 2003.

Johnson, D., Utembe, S. R., Jenkin, M. E., Derwent, R. G., Hayman, G. D., Alfarra, M. R., Coe, H., and McFiggans, G.: Simulating regional scale secondary organic aerosol formation during the TORCH 2003 campaign in the southern UK, Atmos. Chem. Phys., 6, 403-418, 2006, http://www.atmos-chem-phys.net/6/403/2006/.

Kalberer, M., Paulsen, D., Sax, M., Steinbacher, M., Dommen, J., Prevot, A. S. H., Fisseha, R., Weingartner, E., Frankevich, V., Zenobi, R., and Baltensperger, U.: Identification of polymers as major components of atmospheric organic aerosols, Science, 303, 1659-1662, 2004.

Katrib, Y., Martin, S. T., Rudich, Y., Davidovits, P., Jayne, J. T., and Worsnop, D. R.: Density changes of aerosol particles as a result of chemical reaction, Atmos. Chem. Phys., 5, 275-291, 2005, http://www.atmos-chem-phys.net/5/275/2005/.

King, S. M., Rosenorn, T., Chen., Q., Shilling, J. E., and Martin, S. T.: CCN activity of mixed sulfate/SOA aerosols, Geophys. Res. Lett., 34, L24806, doi:10.1029/2007GL030390, 2007.

Kleindienst, T. E., Smith, D. F., Li, W., Edney, E. O., Driscoll, D. J., Speer, R. E., and Weathers, W. S.: Secondary organic aerosol formation from the oxidation of aromatic hydrocarbons in the presence of dry submicron ammonium sulfate aerosol, Atmos. Environ., 33, 3669-3681, 1999.
Kostenidou, E., Pathak, R. K., and Pandis, S. N.: An algorithm for the calculation of secondary organic aerosol density combining AMS and SMPS data, Aerosol Sci. Tech., 41, 1002-1010, 2007.

Lanz, V. A., Alfarra, M. R., Baltensperger, U., Buchmann, B., Hueglin, C., and Prévôt, A. S. H.: Source apportionment of submicron organic aerosols at an urban site by factor analytical modelling of aerosol mass spectra, Atmos. Chem. Phys., 7, 15031522, 2007, http://www.atmos-chem-phys.net/7/1503/2007/.

Lanz, V. A., Alfarra, M. R., Baltensperger, U., Buchmann, B., Hueglin, C., Szidat, S., Wehrli, M. N., Wacker, L., Weimer, S., Caseiro, A., Puxbaum, H., and Prevot, A. S. H.: Source attribution of submicron organic aerosols during wintertime inversions by advance factor analysis of aerosol mass spectra, Environ. Sci. Technol., 42, 214-220, 2008.

Marcolli, C., Canagaratna, M. R., Worsnop, D. R., Bahreini, R., de Gouw, J. A., Warneke, C., Goldan, P. D., Kuster, W. C., Williams, E. J., Lerner, B. M., Roberts, J. M., Meagher, J. F., Fehsenfeld, F. C., Marchewka, M., Bertman, S. B., and Middlebrook, A. M.: Cluster Analysis of the Organic Peaks in Bulk Mass Spectra Obtained During the 2002 New England Air Quality Study with an Aerodyne Aerosol Mass Spectrometer, Atmos. Chem. Phys., 6, 5649-5666, 2006, http://www.atmos-chem-phys.net/6/5649/2006/.

Pang, Y., Turpin, B. J., and Gundel, L. A.: On the importance of organic oxygen for understanding organic aerosol particles, Aerosol Sci. Tech., 40, 128-133, 2006.

Pankow, J. F.: An absorption-model of gas-particle partitioning of organic-compounds in the atmosphere, Atmos. Environ., 28, 185-188, 1994a.

Pankow, J. F.: An absorption-model of the gas aerosol partitioning involved in the formation of secondary organic aerosol, Atmos. Environ., 28, 189-193, 1994b.

Pankow, J. F. and Asher, W. E.: SIMPOL.1: a simple group contribution method for predicting vapor pressures and enthalpies of vaporization of multifunctional organic compounds, Atmos. Chem. Phys., 8, 2773-2796, 2008, http://www.atmos-chem-phys.net/8/2773/2008/.

Presto, A. A. and Donahue, N. M.: Investigation of alpha-pinene plus ozone secondary organic aerosol formation at low total aerosol mass, Environ. Sci. Technol., 40, 3536-3543, 2006.

Saunders, S. M., Jenkin, M. E., Derwent, R. G., and Pilling, M. J.: Protocol for the development of the Master Chemical Mechanism, MCM v3 (Part A): tropospheric degradation of nonaromatic volatile organic compounds, Atmos. Chem. Phys., 3, 161-180, 2003, http://www.atmos-chem-phys.net/3/161/2003/.

Seinfeld, J. H., Kleindienst, T. E., Edney, E. O., and Cohen, J. B.: Aerosol growth in a steady-state, continuous flow chamber: Application to studies of secondary aerosol formation, Aerosol Sci. Tech., 37, 728-734, 2003.

Seinfeld, J. H. and Pankow, J. F.: Organic atmospheric particulate material, Annu. Rev. Phys. Chem., 54, 121-140, 2003.

Shilling, J. E., Chen, Q., King, S. M., Rosenoern, T., Kroll, J. H., Worsnop, D. R., McKinney, K. A., and Martin, S. T.: Particle mass yield in secondary organic aerosol formed by the dark ozonolysis of $\alpha$-pinene, Atmos. Chem. Phys., 8, 2073-2088, 2008, http://www.atmos-chem-phys.net/8/2073/2008/.

Song, C., Zaveri, R. A., Alexander, M. L., Thorton, J. A., Madronich, S., Ortega, J. V., Zelenyuk, A., Yu, X.-Y., Laskin, A., and Maughan, D. A.: Effect of hydrophobic primary or- 
ganic aerosols on secondary organic aerosol formation from ozonolysis of $\alpha$-pinene, Geophys. Res. Lett., 37, L20803, doi:10.1029/2007GL030720, 2007.

Takegawa, N., Miyakawa, T., Kawamura, K., and Kondo, Y.: Contribution of selected dicarboxylic and $\omega$-oxycarboxylic acids in ambient aerosol to the $\mathrm{m} / \mathrm{z} 44$ signal of an Aerodyne aerosol mass spectrometer, Aerosol Sci. Tech., 41, 418-437, 2007.

Takegawa, N., Miyakawa, T., Kondo, Y., Blake, D. R., Kanaya, Y., Koike, M., Fukada, M., Komazaki, Y., Miyazaki, Y., Shimono, A., and Takeuchi, T.: Evolution of submicron organic aerosol in polluted air exported from Tokyo, Geophys. Res. Lett., 33, L15814, doi:10.1029/2006GL025815, 2006.

Tolocka, M. P., Jang, M., Ginter, J. M., Cox, F. J., Kamens, R. M., and Johnston, M. V.: Formation of oligomers in secondary organic aerosol, Environ. Sci. Technol., 38, 1428-1434, 2004.

Turpin, B. J. and Lim, H.-J.: Species contributions to PM2.5 mass concentrations: Revisiting common assumptions for estimating organic mass, Aerosol Sci. Tech., 35, 602-610, 2001.

Ulbrich, I. M., Canagaratna, M. R., Zhang, Q., Worsnop, D. R., and Jimenez, J. L.: Interpretation of organic components from positive matrix factorization of aerosol mass spectrometric data, Atmos. Chem. Phys. Discuss., 8, 6729-6791, 2008, http://www.atmos-chem-phys-discuss.net/8/6729/2008/.

Volkamer, R., Jimenez, J. L., San Martini, F., Dzepina, K., Zhang, Q., Salcedo, D., Molina, L. T., Worsnop, D. R., and Molina, M. J.: Secondary organic aerosol formation from anthropogenic air pollution: Rapid and higher than expected, Geophys. Res. Lett., 33, L17811, doi:10.1029/2006GL026899, 2006.

White, W. H. and Roberts, P. T.: On the nature and origins of visibility reducing species in the Los Angeles basin, Atmos. Environ., 11, 803-812, 1977.

Yu, J., Cocker III, D. R. , Griffin, R. J, Flagan, R. C., and Seinfeld, J. H.: Gas-phase ozone oxidation of monterpenes: Gaseous and particulate products, J. Atmos. Chem., 34, 207-258, 1999.
Zhang, J., Huf-Hartz, K. E., Pandis, S. N., and Donahue, N. M.: Secondary organic aerosol formation from limonene ozonolysis: Homogeneous and heterogeneous influences as a function of $\mathrm{NO}_{\mathrm{x}}$, J. Phys. Chem. A, 110, 11053-11063, 2006.

Zhang, Q., Alfarra, M. R., Worsnop, D., Allan, J. D., Coe, H., Canagaranta, M., and Jimenez, J. L.: Deconvolution and quantification of hydrocarbon-like and oxygenated organic aerosols based on aerosol mass spectrometry, Environ. Sci. Technol., 39, 49384952, 2005a.

Zhang, Q., Worsnop, D. R., Canagaratna, M. R., and Jimenez, J. L.: Hydrocarbon-like and oxygenated organic aerosols in Pittsburgh: insights into sources and processes of organic aerosols, Atmos. Chem. Phys., 5, 3289-3311, 2005b, http://www.atmos-chem-phys.net/5/3289/2005/.

Zhang, Q., Canagaratna, M. R., Jayne, J. T., Worsnop, D. R., and Jimenez, J.-L.: Time- and size-resolved chemical compositions of submicron particles in Pittsburgh: Implications for aerosol sources and processes, J. Geophys. Res., 110, D070S079, doi:10.1029/2004JD004649, 2005c.

Zhang, Q., Jimenez, J. L., Canagaratna, M. R., Allan, J. D., Coe, H., Ulbrich, I., Alfarra, M. R., Takami, A., Middlebrook, A. M., Sun, Y. L., Dzepina, K., Dunlea, E., Docherty, K., DeCarlo, P. F., Salcedo, D., Onasch, T., Jayne, J. T., Miyoshi, T., Shimono, A., Hatakeyama, S., Takegawa, N., Kondo, Y., Schneider, J., Drewnick, F., Borrmann, S., Weimer, S., Demerjian, K., Williams, P., Bower, K., Bahreini, R., Cottrell, L., Griffin, R. J., Rautianinen, J., Sun, J. Y., Zhang, Y. M., and Worsnop, D. R.: Ubiquity and dominance of oxygenated species in organic aerosols in anthropogenically-influenced nothern hemisphere midlatitudes, Geophys. Res. Lett., 34, L13801, doi:10.1029/2007GL029979, 2007. 